\title{
2D Groundwater Depth for Analysis of The Zone Unconfined Aquifer
}

\author{
M. Juandi ${ }^{1}$, Muh Sarkowi ${ }^{2}$
}

\begin{abstract}
Changes in land use have occurred quite significant in the city of Pekanbaru. The increasing of building spaces, the decreasing of plantations and forests are continues to grow with the increasing of population and industries. This means, it can cause impact on groundwater resources. This condition shall continue in effect, along with the population and industrial growth. This means, it can cause impact on groundwater resources of Pekanbaru City, thus the analysis of groundwater zone of Pekanbaru city is needed. The data used in this research is related with the biophysical and social economic. Data analysis method was using numeric simulation programming using finite difference method. The results showed that in 2016, its depth ranges between 16-46 m, this indicates that the unconfined aquifer was in trapped position but not included to the confined aquifer system. In 2017, it was predicted that the depth is about 6-38 m, and in 2018 the depth of unconfined aquifer will go deeper to $31,4-34 \mathrm{~m}$. This is influenced by the changes of population and industrial and the automation of extraction of groundwater by those population and industrial is getting bigger. While in 2019 and 2020, the depth of the unconfined aquifer will be between $41,8-44,4 \mathrm{~m}$ and $44-46,8 \mathrm{~m}$. It was predicted that the growth of population and industries will grow rapidly in the future. This rapid growth will cause the damage of the aquifer.
\end{abstract}

Keywords-Zone, groundwater, numerical method.

\section{INTRODUCTION}

$\mathrm{T}$ The process of development and construction in the city of Pekanbaru will affect the change of land use or land cover, either gradually or through the development of large-scale space. Today, space available for green open space (RTH) of Pekanbaru City is 6653.47 acres. This RTH is an important issue for the availability of groundwater.

The numbers of land use change will affect less land for groundwater recharge. The extraction of water through wells will result the depression cone. The balance can only be obtained if the rate of groundwater extraction is smaller than the charging by rainwater in the catchment areas [1].

Population growth in the city of Pekanbaru and the development of economic have led to the reduced of green space for the formation of ground water. The environmental damage was also implicitly increased the rate of water crisis. Floods, landslides, and drought were the evidence of environmental degradation which over time tends to increase.

Based on the idea that the utilization of underground water by doing massive extraction without concerning the ability of the aquifer would disrupt the environmental balance, given that the availability of underground water is not evenly distributed in all places and highly dependent on local hydrological conditions, environmental balance became noteworthy because the limited resources of water ground.

The damages of water resources cannot be separated from the land degradation and population pressures. Several factors have caused the problems of groundwater, such as [2]:

${ }^{1}$ Departement of Physics Math and Science Faculty, University of Riau, Pekanbaru,Indonesia juandi_m@rocketmail.com

${ }^{2}$ Geophysical Engineering Department, Lampung University-Indonesia, sarkov323@yahoo.com
1. Rapid growth of industries in an area along with the growth of settlements tends to increase the needs of groundwater.

2. The users of water are differing, thus different in the interests, purposes and how to obtain the water resources.

3. It requires the change of attitude on most of the communities who tend to be wasteful in using the water and neglecting the conservation element.

4. The water crisis due to environmental degradation needs an effort to maintain the existence / availability of groundwater resources.

The characteristic of hydraulic conductivity in the aquifer system is a factor that can affect the condition of underground water [3].The parameter of unconfined aquifer is a physical quantity which is related with the characteristics of the aquifer that plays an important role to determine the sustainability of unconfined aquifer water in a region and serves as the characteristics of the unconfined aquifer, the result of the study showed that the rocks to pass the water in the cavities of rocks without changing the nature of the water has an average number of $1.87 \mathrm{~m} /$ day [4]. Porosity parameters can affect the infiltration water into the underground water system with porosity values in District at Tampan of Pekanbaru range $28.66 \%$ to $59.24 \%$ [5]. While the extraction of groundwater factors can affect the sustainability of the aquifer potential [6].

Math technique can be used to identify the potential of groundwater contamination [7-8], it has succeeded in applying the geo electric method to investigate the subsurface water systems that have been contaminated. The research regarding has conducted the condition of groundwater surface with and without artificial recharge area in Bandung, which showed that there is an influence of recharge area on the condition of groundwater surface. The research has conducted the condition and the potential impact of the utilization of groundwater in Bangkalan, which recommended about the possibility of utilization of groundwater potential [1]. The study of aquifer factors shows the sustainability of unconfined aquifer water [9]. The study conducted about the conservation policy has yet to show the sustainability of unconfined aquifer water [10]. The study by Trabelsi and Zounari showed the impact of groundwater exploitation on the sustainability of water ground. The modeling of groundwater can be used for a better water ground. The modeling of water ground can be used to see the balance in the water ground systems [11-13].

The theory constructed in this study was based on a second order differential equation which has been modified and the theory constructed in this study was based on a second order differential equation which has been modified and then solved numerically using finite difference method (Equation 1).

$$
\frac{a^{2} h}{d_{\alpha}^{2}}+\frac{a^{2} h}{d y^{2}}=\frac{s}{r} \frac{d h}{a} \pm\left(\frac{L_{\Lambda}+K_{p}+E_{a}+E_{i}+F_{p}}{r}\right)
$$

Equation 1 is a formulation of the sustainability theory that will be constructed in this study to analyze the sustainability of water ground. Based on the equation (1) it 
can be explained that the zoning parameters of underground water has been calculated to modeling the unconfined aquifer water system as a function of space (x, y), namely; 1) Land conservation or $L_{k}, 2$ ) Government policies or $K_{p}, 3$ ) water ground extraction or $\mathrm{E}, 4)$. Aquifer parameter or $\mathrm{S}$, and $\mathrm{T}$.

\section{METHODS}

The location of this research is located in the administrative city of Pekanbaru. Geographically it's located at 1000 141- 1010 East longitude 341 and North latitude 00251-00451.

The data collected in this research is related with the aspects of biophysical, social economic, population and other supporting data.

The numerical simulation was using a finite difference method. Domain discretion was done by dividing the area of origin (domain) and a continuous function into discrete points.

\section{RESULTS AND DISCUSSION}

\subsection{Unconfined aquifer depth comparative analysis of Pekanbaru City from 2015 to 2020}

The comparative analysis of unconfined aquifer depth was obtained from completing the Matrix Grid of unconfined aquifer depth of Pekanbaru City using MATLAB program, thus the unconfined aquifer depth comparison of Pekanbaru City can be obtained. The following will be shown unconfined aquifer depth comparison results of Pekanbaru City from 2015 to 2020 as can be seen in Fig. 1 and Fig. 2.

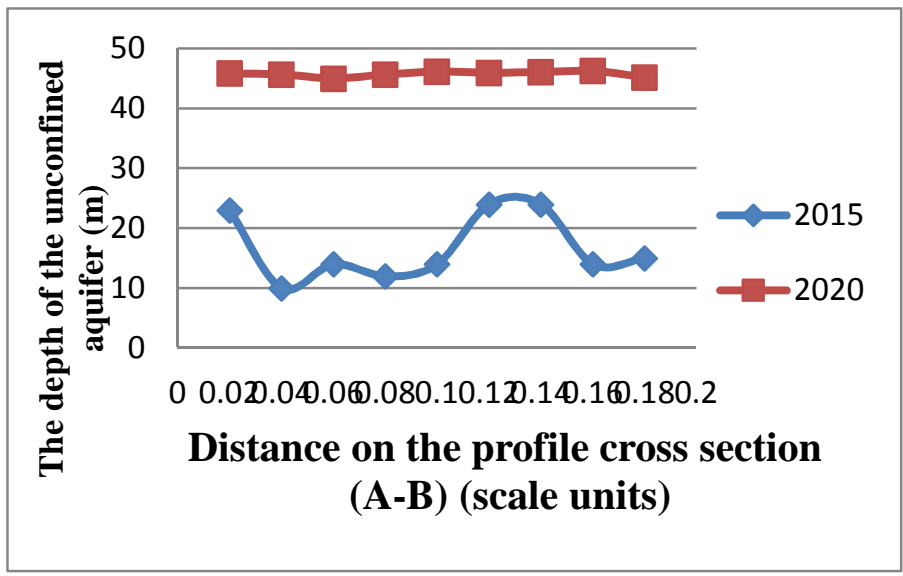

Fig. 1. Profile graph of (A-B) North - South cross section, based on the data of unconfined aquifer depth of Pekanbaru City from 2015 to 2020

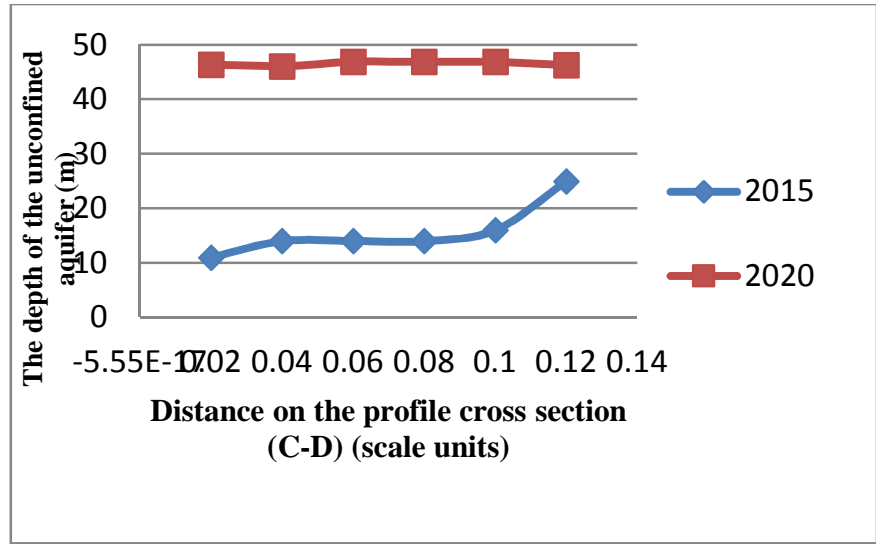

Fig. 2. Profile graph of (C-D) West - East cross section, based on the data ofunconfined aquifer depth of Pekanbaru City from 2015 to 2020.

\subsection{The analysis of unconfined aquifer zone of Pekanbaru} City from 2015 to 2020

The analysis of unconfined aquifer zone of Pekanbaru City from 2015 to 2020 is to predict the unconfined aquifer decreasing percentage. The zone is damage if the subsidence of unconfined aquifer is $>80 \%$, and the zone is safe if the subsidence of unconfined aquifer is $<80 \%$. The percentage of unconfined aquifer decreasing can be seen on Fig. 3 and Fig. 4.

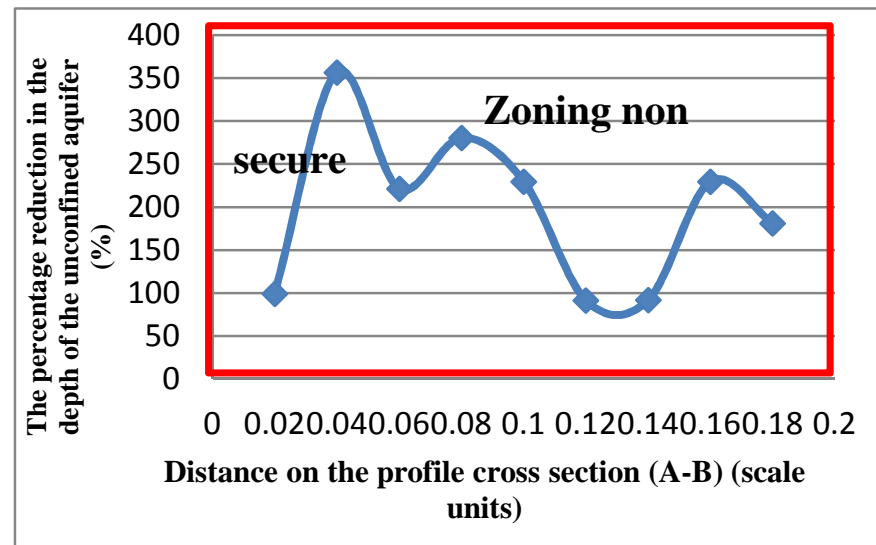

Fig. 3. The graph of unconfined aquifer decreasing percentage of Pekanbaru City on (A-B) cross section from to 2020 .

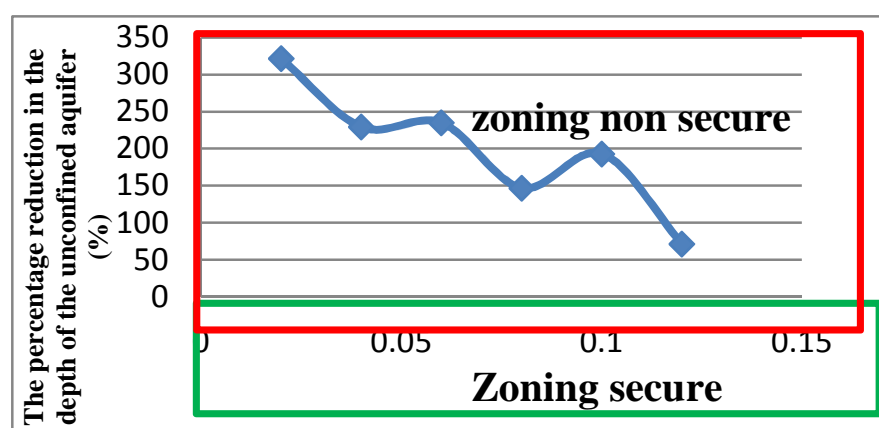

Distance on the profile cross section (C-D) (scale units)

Fig. 4. The graph of unconfined aquifer decreasing percentage of Pekanbaru City on (C-D) cross section from 2015 to 2020

2D mapping of Fig. 3 and 4 predicted that the depth of unconfined aquifer is going deeper. In 2016, the depth is about $16-46 \mathrm{~m}$, it showed that the unconfined aquifer is in a 
trapped position but not included to the confined aquifer system. In 2017, it was predicted that the depth is about 6-38 $\mathrm{m}$, and in 2018, the depth of unconfined aquifer is going deeper to 31.4-34 m. It's due to the changes of population and industrial data and the automation of groundwater extraction by the communities and industries is getting bigger. Meanwhile, the depth of unconfined aquifer in 2019 and 2020 is increasing to 41.8-44.4 and 44-46.8. It was predicted that the growth of population and industries will grow rapidly in the future. This rapid growth of population and industries will damage the aquifer, due to the imbalance of groundwater exploitation with the condition of the water ground. If the aquifer is damage, the communities and the industries would have difficulty getting the water ground. The average of unconfined aquifer depth changes can be seen on Table 1 .

Table 1. The average of unconfined aquifer depth changes based on 2D profile data of 2015-2020.

\begin{tabular}{cccc}
\hline \hline No. & \multicolumn{3}{c}{ The average depth $(\mathbf{m})$} \\
\cline { 2 - 4 } & Year & Cross-section (A-B) & Cross-section (C-D) \\
1 & 2015 & 16.4 & 17.5 \\
2 & 2016 & 22.93 & 23.01 \\
3 & 2017 & 28.63 & 32,35 \\
4 & 2018 & 32.13 & 32.17 \\
5 & 2019 & 43.38 & 42.67 \\
6 & 2020 & 45.80 & 45.77 \\
\hline \hline
\end{tabular}

From the result of Table 1, the graph of unconfined aquifer average depth changes of 2015 to 2020 on the years of (A-B) and (C-D) cross Section was obtained.

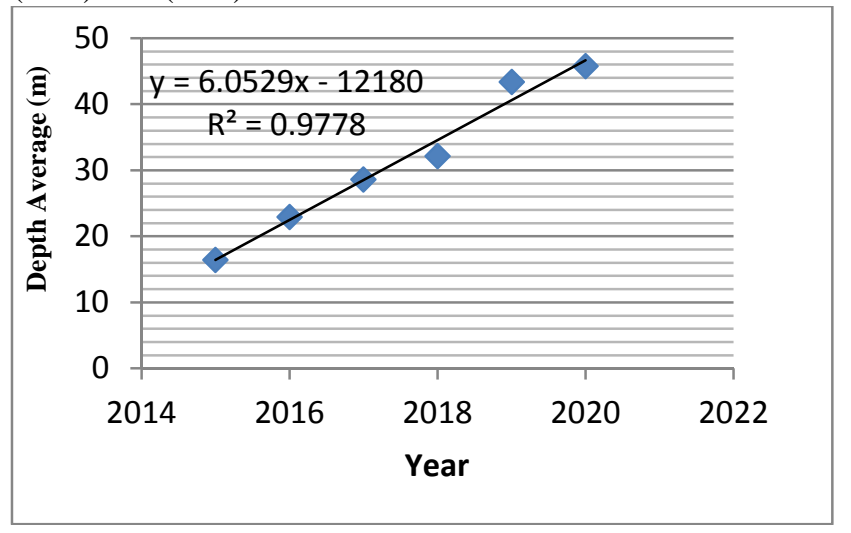

Fig. 5. The graph of unconfined aquifer average depth changes of Pekanbaru City on (A-B) cross section of 2015-2020.

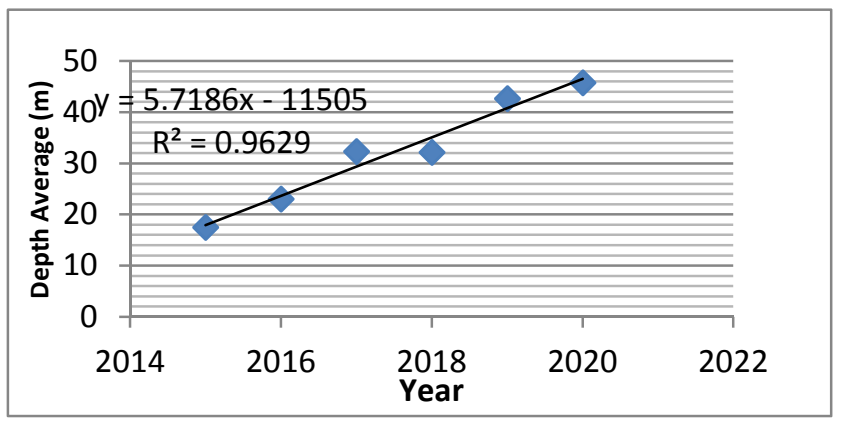

Fig. 6. The graph of unconfined aquifer average depth changes of Pekanbaru City on (C-D) cross section of 2015-2020.

Fig. 5 and Fig. 6 are the graphs of unconfined aquifer average depth changes of Pekanbaru City on (A-B) and (C-D) cross section of 2015 to 2020 . These graphs are linier graphs which have the linear equation of $(A-B) y=$ $6.052 \mathrm{x}-12180$ with a correlation of $\mathrm{R}^{2}=0.977$ and $(C-D) \mathrm{y}=$
$5.718 \mathrm{x}-11505$ with a correlation of $\mathrm{R}^{2}=0.962$. The line equation obtained can be used to determine the depth changes of unconfined aquifer of Pekanbaru City in the future.

Table 2. The zoning of unconfined aquifer decreasing of Pekanbaru City on A-B cross section of 2016.

\begin{tabular}{clll}
\hline \hline No. & \multicolumn{1}{c}{ Districts } & State zoning & \multicolumn{1}{c}{$\begin{array}{c}\text { Large } \\
\left(\mathbf{k m}^{\mathbf{2}}\right)\end{array}$} \\
\hline \hline 1 & Rumbai & Zoning secure & 128.85 \\
2 & Senapelan & Zoning secure & 6.65 \\
3 & Sukajadi & Zoning secure & 3.76 \\
4 & Marpoyan Damai & Zoning secure & 29.79 \\
& & Total area & 169.05 \\
\hline \hline
\end{tabular}

Table 3. The zoning of unconfined aquifer decreasing of Pekanbaru City on C-D cross section in 2016.

\begin{tabular}{clll}
\hline \hline No. & Districts & State zoning & $\begin{array}{c}\text { Large } \\
\left(\mathbf{k m}^{\mathbf{2}}\right)\end{array}$ \\
\hline \hline 1 & Payung Sekaki & Zoning secure & 51.36 \\
2 & Pekanbaru & Zoning secure & 2.26 \\
3 & Lima Puluh & Zoning secure & 4.04 \\
4 & Tenayan Raya & Zoning secure & 171.27 \\
& & Total area & 228.93 \\
\hline \hline
\end{tabular}

The zoning of unconfined aquifer decreasing of Pekanbaru City on A-B cross section has the total safe zone of $169.05 \mathrm{~km}^{2}$ and on (C-D) cross section has the total safe zone of $228.93 \mathrm{~km}^{2}$.

Fig. 5 and Fig. 6 shows the graph of unconfined aquifer decreasing percentage of Pekanbaru City from 2015 to 2017 on (A-B) and (C-D) cross section. It can be seen that the percentage of unconfined aquifer decreasing are $25-195 \%$ and (-20)-225\%, it means that it was predicted that the condition of unconfined aquifer of Pekanbaru City in 2017 are in a safe zone and not in a safe zone. Therefore, the unconfined aquifer decreasing zoning prediction result can be seen on Table 2 and 3.

\section{CONCLUSION}

The result of this study showed that in 2016 the depth of unconfined aquifer in Pekanbaru City is ranges between 16-46 $\mathrm{m}$, indicating that unconfined aquifer is in a trapped position but not included to the confined aquifer system. In 2017, it was predicted that the depth will be around 6-38 m, and in 2018, the depth of unconfined aquifer system will go deeper to $31.4-34 \mathrm{~m}$. It's due to the changes of population and industrial and the automation of groundwater extraction by the communities and the industries is getting bigger. Meanwhile, the depth of unconfined aquifer in 2019 and 2020 is increasing to $41.8-44.4$ and 44-46.8. It was predicted that the growth of population and industries will grow rapidly in the future. This rapid growth of population and industries will damage the aquifer. It can be seen that the percentage of unconfined aquifer decreasing are $25-195 \%$ and $(-20)-225 \%$, it means that it was predicted that the condition of unconfined aquifer of Pekanbaru City in 2017 are in a safe zone and not in a safe zone. 


\section{RECOMMENDATIONS}

Need to do further research to see the influence of artificial ground water recharge to the unconfined aquifer conditions, and the use of other methods for comparison.

\section{ACKNOWLEDGMENTS}

I would like to thank you to RISTEK Higher Education for the source of funding through grants to fundamental advanced year 2, 2016.

\section{REFERENCES}

[1] Hutasoit, L. M., Groundwater Surface conditions with and withou impregnation Made in Bandung Regional, Journal of Geology Indonesia. 2009, 01.4, No.3, pp.177-188.

[2] Mawardi, I., 2010. Damage Decreased Watershed And Carrying Capacity of Water Resources Efforts In Java And Handling, Journal Hidrosfir Indonesia, Vol. 5, No.2.

[3] Juandi, M, 2012. Application of Basic Concepts resistivity to determine Conductivity the aquifer system, DIPA UR

[4] Juandi, M, 2013 Application Geoelectric method to determine the material characterization of land based systems unconfined aquifer transmissivity coefficient in Pekanbaru, DIPA UR.
[5] Juandi, M., Quantitative Models to Study the Soil Porosity as Function of Soil Resistivity, Open Journal of Modern Hydrology, 2016, 6 Pp.253-262.

[6] Adhikary, S.K., Chaki, T., Rahman, U.M., and Gupta, A.D., Estimating Groundwater Recharge Into A Shallow Unconfined Aquifer In Bangladesh, Journal of Engineering Science, 2013, 04(1), pp.11-22.

[7] Laton, W. R., Whitley, R. J., and Hromadka, I. T. V., A new Mathematical technique for identifying potential sources of Groundwater contamination. Hydrogeology Journal, 2007,(15). Pp.333-338.

[8] Neyamadpour, A., Samsudin, T., and Abdullah, W. A. T., An Application of three-Dimensional electrical resistivity imaging for the detection of undergrouand wastewater system, 2009,Geophys (53).pp. 389-402.

[9] Wahyudi, H., Conditions and Potential Impact on Soil Water Utilization Bangkalan journal Applications, 2009, Vol.7, No.1. pp. 1419.

[10] Waspodo, R.S. B., Groundwater Flow Modeling In Aquifer Depressed Using Different Methods Up, Bulletin Technicality Agriculture, 2002, Vol.16, No. 2.

[11] Subastaryo, 2003. Groundwater Management Model In Regions In Semarang District catchment basin. Semarang Java Central. Post Graduate Thesis, University of Diponegoro.

[12] Abdulla, F., and Al-Assad, T.Modeling Of Ground Water Flow For Mujib Aquifer, Jordan, Journal Earth Syst, 2006, Sci, 115, No.3.pp 289-297.

[13] Ahmed, I., Umar R., Groundwater flow modeling of Yamuna-Krisni Interstream, a Part of Central Ganga Plain Uttar Pradesh, Journal Earth Syst, 2009, Sci, 118, No. pp. 507-523. 